ISSN 2338-4778 (Print)

\title{
Learning Strategies Used By The Students of English Departement of Stain Palopo
}

\author{
Yuyun Ruqiyyat Said \\ yruqiyyat@gmail.com
}

Institut Agama Islam Negeri Palopo

\author{
Received : 12 Mei 2018, Accepted : 28 Mei 2018 \\ URL $\quad: \underline{\text { http://ejournal.iainpalopo.ac.id/index.php/ideas }}$
}

\begin{abstract}
This research aimed at finding out the learning strategy used by sixth semester students of English Department of STAIN Palopo This research applied quantitative method, the data were collected from questionnaire of SILL (Strategies Inventory of Language Learning) developed by Oxford; there are six types of learning strategies, they are memory, cognitive, compensation, metacognitive, affective and social strategies. The researcher used Strategy Inventory for Language Learning (SILL) version 7.0 as instrument to collect the data in this research. Questionnaire was used to get quantitative data about learning strategies of the students.. The result of the study shows that the most frequently used learning strategy by students is meta cognitive; this strategy is also the highest level of usage. These strategies help students to coordinate their learning and plan language leaning in efficient way. Metacognitive strategies (e.g., identifying one's own learning style preferences and needs, planning for an target language task, gathering and organizing materials, arranging a study source and a schedule, monitoring mistakes, and evaluating task success, and evaluating the success of any type of learning strategy) are employed for managing the learning process overall.
\end{abstract}

Keywords: Learning Strategies; English Learning 


\section{Introduction}

During the learning process, one might find that some people can learn every subject or several subjects very quickly and well. On the other hand, some people have problems in learning. Therefore, many researches try to find how learners go about learning something, what makes learners successful at learning something, and why some people are more effective at learning than others. Williams \& Burden (1997) point out, that can only be answered by investigating learning strategies.

Learning strategies are the conscious thoughts and actions that learners take in order to achieve a learning goal. Strategic learners have metacognitive knowledge about their own thinking and learning approaches, a good understanding of what a task entails, and the ability to orchestrate the strategies that best meet both the task demands and their own learning strengths (Chamot, 2004).

Language learning strategies are good indicators of how learners approach tasks or problems encountered during the process of language learning. In other words, language learning strategies, while nonobservable or unconsciously used in some cases, give language teachers valuable clues about how their students assess the situation, plan, select appropriate skills so as to understand, learn, or remember new input presented in the language classroom. Research on language learning strategies began with the strategies of the "good language learner" by Rubin (1975) and Stern (1975). From these initial research efforts, numerous researchers have attempted to emphasize the importance of language learning strategy use by successful language learners (e.g., Abraham \& Vann, 1987, 1990; Chamot \& Kupper, 1989; Naiman, Frolich, Stern, and Todesco, 1978; O’Malley \& Chamot, 1990; Oxford et al., 1989,1993, 1995; Politzer \& McGroarty, 1985; Ramsey, 1980; Reiss, 1983). The researchers believe that language learning strategy plays a significant role in L2/FL learning, due to the fact that language learning strategies that can help learners to facilitate the acquisition, storage, retrieval or use of information and increase self-confidence.

Williams \& Burden (1997) indicated that when students are involved in a learning task, they have several resources which they use in different ways to finish or solve the task, so this can be termed process of learning strategy. This explanation might be too abstract to understand, so it may be easier to say that learning strategy is learning skills, learning-to-learn skills, thinking skills, problem skills or, in other words the methods which learners use to intake, store, and retrieve during the learning process. Oxford (1990) defines learning strategies as "specific actions taken by the learner to make learning easier, faster, more enjoyable, more self-directed, more effective, and more transferable to new situations".

Despite the common systems of memory and language and cognitive 
processing in the brain (Cook 2001), language learners vary in terms of factors such as: aptitudes, demographic variables, affective variables, learning styles, and learning strategies when they start learning the second language. These variable factors have profound effects on how the learners approach language learning tasks and how successful they are. Strategies that applied will be different from learners to learners. The choice of the strategies is also determined by the personality of the learners. Freeman (1991) stated that the personality has a lot to do with how fast and easily the learners learn a foreign language. If the learners are more outgoing and not afraid to take a risk, the learners are the type of person who is not afraid to take a risk, the learners are the type of person who is not afraid to practice our new language skills. In addition, being aware of how the learners learn is an important factor. If the learners know how to take charge of their learning, the learners will learn faster.

They do not only aid language learning, but also the learning of other subjects such as math, chemistry, etc. In other words, when learners start to learn something, they have the ability to respond to the particular learning situation and to manage their learning in an appropriate way. Thus, learning strategy is like footballers who use tactics in order to win a game, when they are in the stadium. Learners use learning strategies in order to learn something more successfully.

Based on finding of the research and theory about learning strategies above, can conclude that learning strategies have been applied by many students especially students of university. It is possible also occur on students of English Department of STAIN Palopo. Varieties of learning strategies automatically are used by them.

From fact showed above the researcher was interest in conducting a research entitled "Learning Strategies Used by the Students of English Department of STAIN Palopo".

\section{REVIEW OF RELATED LITERATURE}

Learning strategies have received much attention since the late 1980s (Oxford, 2008) and the investigation of language learning strategies has advanced our understanding of the processes learners use to develop their skills in a second or foreign language. Reiss (1985) reported that during the past decade, the emphasis on foreign language research has shifted from the teacher to the learner, and educational research had identified a number of factors that account for some of the differences in how students learn. Oxford \& Lee (2008) conducted the research entitled 'Understanding EFL Learners' Strategy Awareness". Their intention is to find out whether or not there were significant main effects or interaction effects of the variables on strategy use: (1) gender, (2) 
major, (3) education level, (4) English learning self image, (5) importance of English, and (6) strategy awareness, they found out that except for major and gender, all the other variables had significant influences on strategy use and strategy awareness. Gender and major were expected to be helpful indicators of successful learning, but they turned out not to affect strategy use and awareness alone. However, when gender and major are combined with other variables, they interactively affected strategy use and awareness. The term learning strategies refers to techniques, behaviours, actions, thought process, problem solving, or study skills taken by the learner to make learning easier, faster, more self-directed, more effective, and more transferable to a new situation (Oxford and Crookall 1989; Oxford 1990), and enable more independent, autonomous, lifelong learning (Allwright 1990 cited Ehrman et al. 2003). There are many other definitions of learning strategies. All of them imply learner"s conscious movement toward a language goal (Bialystok 1990; Oxford 1990, 1996; cited Ehrman et al. 2003). Oxford (1990) classified learning strategies into six groups, they are memory, cognitive strategies, compensation strategies, metacognitive strategies, affective strategies, and social strategies. Those six groups then classified into two categories, they are direct strategies divided into memory strategies, cognitive strategies, compensation strategies and indirect strategies divided into metacognitive strategies, affective strategies, and social strategies.

Table Direct and Indirect Strategies

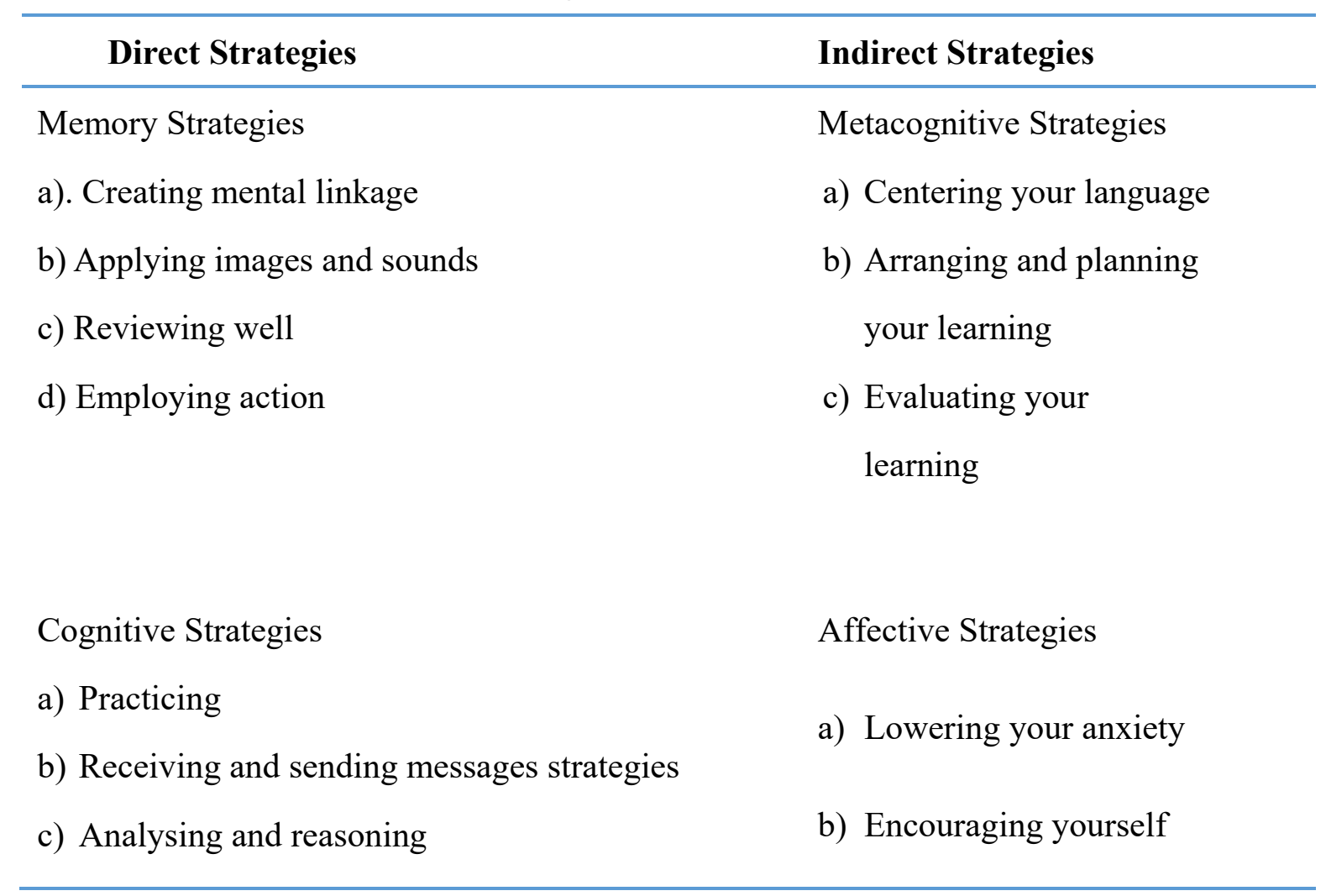


d) Creating structure for input and output

Compensation Strategies

a) Guessing intelligently

b) Overcoming limitations in speaking and writing c) Taking your emotional temperature

a) Asking question

b) Cooperating with others

c) Emphathizing with

others

The following is the explanation of classification of learning strategies provided by Oxford.

1. Direct strategies

Language learning strategies that directly involved the target language are called direct strategies. All direct strategies require mental processing of the language.

2. Indirect Strategies

Indirect strategies are divided into metacognitive strategies, affective strategies, and social strategies. All these strategies are called as 'indirect' because they support and manage language learning without directly involving the target language. Indirect strategies are useful in virtually all language learning situations and are applicable to all four language skills : listening, speaking, reading, and writing.

Many of the initial studies on language learning strategies were aimed at defining the "Good" language learner. As the knowledge of second language acquisition increased during the 1970s, teachers and researchers concluded that no single method of language teaching and research findings would mark the start of universal success in teaching a second language (Brown, 2007). It was realized that certain learners seemed to be successful regardless of methods or teaching techniques. "Certain people appeared to be endowed with abilities to succeed; others lacked those abilities" (p.132). Observations and research studies led researchers (Rubin, 1975; Stern, 1975; Rubin and Thompson, 1994) to describe "good" language learners in terms of personal characteristics, styles, and strategies. They believe that good language learners:

1. Find their own way, taking responsibility for their own learning, 
2. Organize information about language,

3. Are creative, and try to feel the language by experimenting its grammar and words,

4. Create opportunities for practice in using the language inside and outside the classroom,

5. Learn to live with uncertainty by not getting confused and by continuing to talk or listen without understanding every word,

6. Use memory strategies to bring back what has been learned,

7. Make errors work for them and not against them,

8. Use linguistic knowledge, including knowledge of the first language, in learning a second language

9. Use contextual cues to help them in comprehension,

10. Learn to make intelligent guesses,

11. Learn chunks of language as wholes and formalized routines to help them perform "beyond their competence",

12. Learn to use certain tricks to keep conversations going,

13. Learn certain production strategies to fill in gaps in their own competence,

14. Learn different styles of speech and writing and learn to vary their language regarding the formality of the situation..

\section{Method}

This research applied quantitative method, the data were collected from questionnaire of SILL (Strategies Inventory of Language Learning) developed by Oxford; there are six types of learning strategies, they are memory, cognitive, compensation, metacognitive, affective and social strategies.

The researcher used Strategy Inventory for Language Learning (SILL) version 7.0 as instrument to collect the data in this research. Questionnaire was used to get quantitative data about learning strategies of the students. One of the most widely used measures has been the Strategy Inventory for Language Learning (SILL). (Dörnyei 2005, White, Schramm and Chamot 2007). It is a structured questionnaire, aiming to assess how often learners employ specific language learning strategies.

It equips teachers with the strategy profile of their students and uncovers to learners the kinds of strategies they resort to when learning English as a second or foreign language (Oxford 1990).

The version 7.0 of SILL contains of 50 items, each item describes a language learning strategy and students were asked to respond to the SILL items by indicating how often they employ the strategies and SILL characterized into six subscales: (a) memory strategies (items 1 to 9), (b) cognitive strategies 
(items 10 to 23), (c) compensation strategies (items 24 to 29), (d) metacognitive strategies (items 30 to 38), (e) affective strategies (items 39 to 44), (f) social strategies (items 45 to 50 ). These SILL 50 items are evaluated on a five-point Likert scale ranging from 1 to 5 . The number indicates how often the learner uses the strategies.

Never or almost never true of me $=1$

Generally not true of me $\quad=2$

Somewhat true of me $\quad=3$

Generally true of me $\quad=4$

Always or almost always true of me $=5$

\section{Results}

The most frequently used learning strategy by sixth semester students of English Department of STAIN Palopo is metacognitive; this strategy is also the highest level of usage. These strategies help students to coordinate their learning and plan language leaning in efficient way. Metacognitive strategies (e.g., identifying one's own learning style preferences and needs, planning for an target language task, gathering and organizing materials, arraging a study soace and a schedule, monitoring mistakes, and evaluating task success, and evaluating the success of any type of learning strategy) are employed for managing the learning process overall. Among native English speakers learning foreign languages, Purpura (in Oxford, 2003) found that metacognitive strategies had 'a significant, positive, direct effect on cognitive strategy use, providing clear evidence that metacognitive strategy use has an executive function over cognitive strategy use in task completion.

In the questionnaire of SILL (strategy inventory for language learning) developed by Rebecca Oxford the students marked their learning strategies $A$ to F on 5-point scale (SILL-Oxford), strategy A refers to Memory strategies, which "help learners store in memory the important things they hear or read in the new language, thus enlarge their knowledge base and help learners to retrieve information from memory when they need to use it for comprehension or production;" this category of strategies is used at the low level of frequency. These strategies help students to coordinate their learning and plan language leaning in efficient way.

Category B refers to Cognitive strategies, which are "skills that involve manipulation or transformation of the language in some direct way, e.g., through reasoning;" this category of strategies is used at the medium of frequency. Category $\mathrm{C}$ refers to Compensation strategies, which are "behaviors used to compensate for missing knowledge of some kind, e.g., inference (guessing) while listening or reading;" this category of strategies is used at the low level of 
frequency. Category D refers to Metacognitive strategies, which are "behaviors used for centering, arranging, planning, and evaluating one's learning;" this category of strategies used at a high level of frequency. Category $E$ refers to Affective strategies, which are "techniques like self-reinforcement and positive self-talk;" this category of strategies is used at the low level of frequency. Category F refers to Social strategies, which are "actions involving other people in the language learning process;" this category of strategies is used at the low level of frequency.

This result is consistent with several related studies. For examples, Carol (2010) who found the strategies used by two successful learners, Nina and Kira, and considers the effect of other learner variables (motivation, nationality, age, gender, personality) on successful language learning. The research concludes that succesful learners was used metacognitive strategies. The second is Arifin (2000). He found that English learning behavior of Indonesian adults may be characterized to fall into transitional phase from cognitive orientation to social and metacognitive learning pattern.

The third are Chang, Ci-Yi et al. (2007). They found that statistically significant differences were found in the use of cognitive strategies, metacognitive strategies, social strategies and overall strategies with regard to gender. They also found statistically significant differences were found in the use of six subcategories of language learning strategies and overall strategies with regard to major. The study was designed to investigate the influence of gender and major on college EFL learning strategy use in Taiwan.

\section{Conclusion}

From the findings and discussion of the research, it is found that the most frequently used learning strategy by sixth semester students of English Department of STAIN Palopo is metacognitive; this strategy is also the highest level of usage. These strategies help students to coordinate their learning and plan language leaning in efficient way. Metacognitive strategies (e.g., identifying one's own learning style preferences and needs, planning for an target language task, gathering and organizing materials, arraging a study soace and a schedule, monitoring mistakes, and evaluating task success, and evaluating the success of any type of learning strategy) are employed for managing the learning process overall. Among native English speakers learning foreign languages, Purpura (in Oxford, 2003) found that metacognitive strategies had 'a significant, positive, direct effect on cognitive strategy use, providing clear evidence that metacognitive strategy use has an executive function over cognitive strategy use in task completion.

\section{References}


Learning Strategies Used by the Students of English Department of STAIN Palopo

Abhakorn. (2008). The Implications of Learner Strategies For Second or Foreign Language Teaching. ARECLS, Vol.5,( 186-204).

Anna Uhl Chamot. (2004). Issues in Language Learning Strategy Research and Teaching. Electronic Journal of Foreign Language Teaching. Vol. 1, No. 1, (pp. 14-26.) (C) Centre for Language Studies. National University of Singapore.

Atmowardoyo, Haryanto. (2000). Research Methods For Language And Literature Studies. Makassar. Badan penerbit UNM.

Cambridge Advance Learner's Dictionary $3^{\text {rd }}$ Edition. (2008). Cambridge University Press:

Chandler, J., R. Lizotte and M. Rowe. (1998). Adapting Teaching Methods to learners' Preferences, Strategies, and Needs. College ESL, 8 (pp.48-69).

Chang S.J. (1990). A Study of Language Learning Behaviors of Chinese Learners at the University of Georgia and the Relation of those Behaviors to Oral Proficiency and Other factors. Unpublished Doctoral Dissertation, University of Georgia, Athens, GA.

Chang, Ching-Yi \& Liu, Shu-Chen \& Lee, Yi-Nan. (2007). A Study of Language Learning Strategies Used by College EFL Learners in Taiwan.

Chang, S. J. and S. C. Huang. (1999). Language Learning Motivation and Language Strategies of Taiwanese EFL Students. Washington, DC: Department of Education. [ERIC: Document Reproduction Service No. ED371589].

Chen, Yueh-miao. (2005). The Learning Strategies of Taiwanese University Students: English Majors Versus Non-English Majors and Males Versus Females. Indonesian Journal of English Language Teaching, Vol. 1/no.2.

Dhanapala, K. V. (2007). Focus on Language Learning Strategies of Advanced Learners in Japan and Sri Langka. Hiroshima University. Journal of International Development and Cooperation, Vol. 13, No. 1 (pp. 153-164).

Ehrman, M., and Oxford, R. (1990). “Adult Language Learning Styles and Strategies in An Intensive Training Setting." Modern Language Journal 74/3, (pp.27-311). 
Ehrman, M., and Oxford, R. (1989). Effects of Sex Differences, Career Choice, and Psychological Type on Adult Language Learning Strategies. The Modern Language Journal, 73/1, (pp. 1-13).

Gay, et al. (2006). Educational Research. New Jersey: Pearson Prentice Hall.

Ghadesi, M. (1998). Language Learning Strategies of Some University Students in Hong Kong. Paper presented at the $9^{\text {th }}$ English in Southeast Asia Conference. Brunei.

Griffiths. (2010). Strategies of Successful Language Learners. JELS, Vol. 1, No. 3, Spring (pp.1-18).

Green, J. M., and Oxford, R. (1995). A Closer Look at Learning Strategies, L2 Proficiency, and Gender. TESOL Quarterly, 29(2), (pp. 261-297).

Larsen-Freeman, Diane, and Long, Michael H. (1991). An Introduction to Second Language Acquisition Research. New York: Longman Inc.

Mamuna. (2003). Language Learning Strategies Employed by L2 Learners. Department of English, Islamia University Bahawalpur. Journal of Research (Faculty of Languages \& Islamic Studies) Vol.4

Nyikos, Matha. (2008). Gender and Good Language Learners, in Lesson From Good Language Learners. Cambriadge University press; pp.73-82.

O’Malley, J. M., Chamot, A. U., Stewner-Manzanares, G., Russo, R., \& L. Küpper. (1985). Learning Strategy Applications with students of English as a Second Language. TESOL Quarterly, 19 (3), (pp. 557-584).

O’Malley, J. M. and Chamot, A. U. (1990). Learning Strategies in Second Language Acquisition. Cambridge: Cambridge University Press.

Oxford, R.L. (1990a). Language Learning Strategies and Beyond: A Look at Strategies in the Context of Styles. In S.S. Magnan (Ed.), Shifting the Instructional Focus to the Learner (pp. 35-55). Middlebury, VT: Northeast Conference on the Teaching of Foreign Languages.

Oxford. R. L. (1990b). Language Learning Strategies: What Every Teacher Should Know. Boston: Heinle \& Heinle. 
Learning Strategies Used by the Students of English Department of STAIN Palopo

Oxford, R. L., and Crookall, D. (1989). Research on Language Learning Strategies: Method, Findings, and Instructional Issues. Modern Language Journal, 73, (pp. 404-419).

Oxford, R. and M. Nyikos. (1989). Variables Affecting Choice of Language Learning Strategies by University Students. Modern Language Journal, 73, (pp. 291-300).

Peacock, M. and B. Ho. (2003). Students Language Learning Strategies Across Eight Disciplines. International Journal of Applied Linguistic, 13, (pp. 179-200).

Purwana, (2012). Learning Strategies Of Sixth Semester Students Of English Department Of Tarbiyah Faculty At UIN Alauddin Makassar: Unpublished thesis-UNM.

Rahimi, Riazi and Saif. (2004). An Investigation into the Factors Affecting the Use of Language Learning Strategies By Persian EFL Learners. RCLA. CJAL Journal, 11, (pp.31-60).

Rigney, J. W. (1978). Learning Strategies: A Theoretical Perspective. In H. F. O’Neil, Jr. (Ed.), Learning Strategies (pp. 165-205). NY: Academic

Rubin, J. (1987). Learner Strategies: Theoretical Assumptions, Research History and Typology. In A. Wenden and J. Rubin (Eds.), Learner Strategies and Language Learning. (pp. 15-29). Englewood Cliffs, New Jersey: Prentice Hall.

Rubin, J. W. (1975). What the 'Good Language Learner' Can Teach Us. TESOL Quartely, 9, (pp.41-51).

Rubin, and Wenden, A. (1987). Learner Strategies in Language Learning. Englewood Cliffs: Prentice Hall.

Rubin, J., and Thompson, I. (1982). How to be a More Successful Language Learner. Boston: Heinle \& Heinle.

Weda, Sukardi. (2005). English Learning Strategies Employed by Senior Secondary School Students in Makassar. Makassar: Unpulished Thesis-Unhas.. 